\title{
Current Progress of Si/Graphene Nanocomposites for Lithium-Ion Batteries
}

\author{
Yinjie Cen ${ }^{1}$ (D), Richard D. Sisson ${ }^{1}$, Qingwei Qin ${ }^{2, *}$ and Jianyu Liang ${ }^{1, *}$ \\ 1 Department of Mechanical Engineering, Worcester Polytechnic Institute, Worcester, MA 01609, USA; \\ ycen@wpi.edu (Y.C.); sisson@wpi.edu (R.D.S.) \\ 2 The Key State Laboratory of Refractories and Metallurgy, Wuhan University of Science and Technology, \\ Wuhan 430081, China \\ * Correspondence: qingweiqin@126.com (Q.Q.); jianyul@wpi.edu (J.L.); \\ Tel.: +86-189-7162-1606 (Q.Q.); +1-508-831-5178 (J.L.)
}

Received: 28 January 2018; Accepted: 15 March 2018; Published: 19 March 2018

\begin{abstract}
The demand for high performance lithium-ion batteries (LIBs) is increasing due to widespread use of portable devices and electric vehicles. Silicon (Si) is one of the most attractive candidate anode materials for next generation LIBs. However, the high-volume change $(>300 \%)$ during lithium ion alloying/de-alloying leads to poor cycle life. When Si is used as the anode, conductive carbon is needed to provide the necessary conductivity. However, the traditional carbon coating method could not overcome the challenges of pulverization and unstable Solid Electrolyte Interphase (SEI) layer during long-term cycling. Since 2010, Si/Graphene composites have been vigorously studied in hopes of providing a material with better cycling performance. This paper reviews current progress of $\mathrm{Si} /$ Graphene nanocomposites in LIBs. Different fabrication methods have been studied to synthesize $\mathrm{Si} / \mathrm{Graphene}$ nanocomposites with promising electrochemical performances. Graphene plays a key enabling role in $\mathrm{Si} /$ Graphene anodes. However, the desired properties of graphene for this application have not been systematically studied and understood. Further systematic investigation of the desired graphene properties is suggested to better control the $\mathrm{Si} /$ Graphene anode performance.
\end{abstract}

Keywords: Si anode; graphene; nanocomposites; lithium-ion batteries

\section{Introduction}

Carbon coating has been vigorously studied for many energy sources such as solar cells, fuel cells and LIBs [1-3]. The carbon coating method has proven itself as simple and efficient for property enhancement. Typically, carbon precursors are introduced to the surface of active material and calcinated at an elevated temperature to acquire the final product coated by layers of carbon. For example, anatase $\mathrm{TiO}_{2}$ with carbon coating has shown enhanced photoactivity under UV irradiation [4]. Carbon coating on the $\mathrm{SiC}$ nanowires (NWs) in $\mathrm{SiC}$ matrix composite has been used to increase the fracture toughness and flexural strength [5]. Ti bipolar plates coated with amorphous carbon for polymer electrolyte membrane fuel cells (PEMFC) have been observed to demonstrate lower contact resistance and higher output power than that of non-coated Ti bipolar plates [6].

Lithium-ion battery (LIB) has become the prevailing power supply for portable electronic devices since its first commercialization in 1991 by Sony [7]. LIB offers several advantages including high energy density, good charging rate, long cycle life and high-power retention [8-10]. In addition, LIB is currently the most popular alternative option to replace the non-renewable fossil fuel for powering vehicles [11,12]. High capacity, fast charging rate and low cost are demanded by customers. Developing new electrode materials for next generation LIBs remains a challenge. 
Currently, $\mathrm{Si}$ is one of the most attractive candidate anode materials for next generation LIBs. The commonly used graphite anode provides a capacity of $372 \mathrm{mAh} / \mathrm{g}$ at its highest lithiated state of $\mathrm{LiC}_{6}$ [13]. Si can provide a capacity of $3578 \mathrm{mAh} / \mathrm{g}$ by forming $\mathrm{Li}_{15} \mathrm{Si}_{4}$ at room temperature [14]. It also has the theoretical highest capacity of $4200 \mathrm{mAh} / \mathrm{g}$ by forming $\mathrm{Li}_{22} \mathrm{Si}_{5}$ at elevated temperatures [15]. In addition to its 10 times capacity increase when compared to graphite, $\mathrm{Si}$ also has a lower, more favorable discharging potential of about $0.3 \mathrm{~V} \mathrm{vs}$. $\mathrm{Li} / \mathrm{Li}^{+}$, which is very close to lithium metal $[14,16]$. This low potential results in a high-power battery since the greater voltage difference between cathode and anode, the more power the full cell can deliver. Furthermore, Si ranks as the 2nd most abundant element in Earth's crust next to oxygen [17] and it is environmental friendly.

The main challenges that prevent Si-based anode from replacing graphite anode are the huge volume expansion during lithiation processes, slow lithium diffusion rate, and low electronic conductivity. In fact, the volume of lithiated $\mathrm{Li}_{15} \mathrm{Si}_{4}$ is $370 \%$ of delithiated $\mathrm{Si}$ [18]. There are two primary approaches to overcome the consequences of the structural collapse due to volume change, nanotechnology and carbon coating. Nanosized Si-based anode exhibits improved cycle life and high rate stability compared with bulk Si-based anode [19,20]. Nanosized Si-based anode has a very high surface area, which allows for low charge transfer resistance and benefits the rate of the lithiation and delithiation processes. The fast lithium ion transportation rate can lead to an improved high rate performance and reduce the pulverization. In Si-based anode, carbon coating provides an electron pathway to loose Si clusters. Nanosized Si in combination with different forms of carbon materials have been explored for high performance $\mathrm{Si} / \mathrm{C}$ nanocomposite anode. These carbon forms include 0-D (nanodot and nanoparticle) [15], 1-D (nanowire and nanotube) [21], 2-D (graphene and thin film) $[22,23]$ and 3-D (porous and hierarchical) [24,25] structures. The representing cycling performances of various reported $\mathrm{Si} / \mathrm{C}$ anodes are given in Table 1. Among them, Si/Graphene nanocomposite has demonstrated great potential.

Since 2010, the number of scientific publications on Si/Graphene anode has been steadily increasing according to the Web of Science search results shown in Figure 1. It is obvious that the number of published articles with topics on "Silicon + Graphene + Anode" increased quickly over the years. The search in Google Scholar using keywords "Silicon + Graphene + Anode + Lithium + Battery" resulted in a much larger number of publications in a similar trend. Given the interest and amount of work done in this material, a review on the state of the art of $\mathrm{Si} / \mathrm{Graphene}$ nanocomposite anode is certainly desirable. Through our review, it was clear that even though much effort has been investing in the synthesis of $\mathrm{Si} /$ Graphene nanocomposite anodes, the exact working mechanism of graphene in this composite electrode has not yet been carefully studied. A better understanding of the desirable properties of Graphene in this composite electrode will benefit future efforts on $\mathrm{Si} / \mathrm{Graphene}$ nanocomposite anodes.

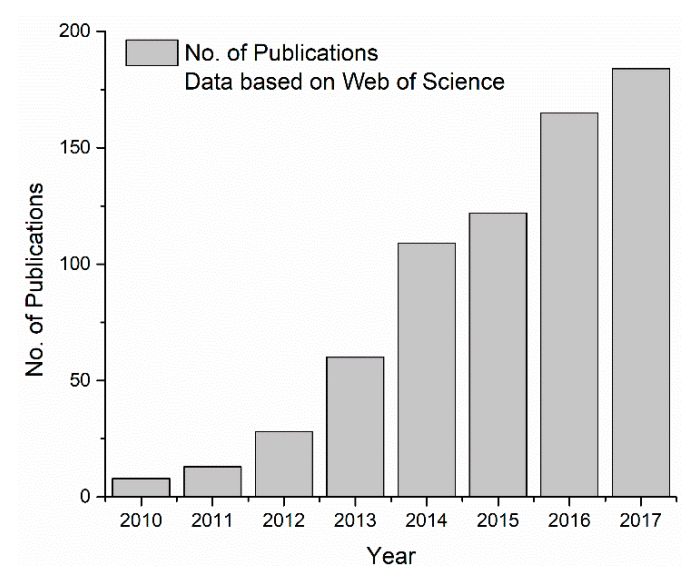

Figure 1. Number of publications in Web of Science with topic on "Silicon + Anode + Graphene" from 2010 to 2017. 
Table 1. Selected examples of Si anode with different carbon forms.

\begin{tabular}{ccccc}
\hline \multirow{2}{*}{ Carbon Form } & 0-D [15] & 1-D [21] & 2-D [22] & 3-D [25] \\
\cline { 2 - 5 } & Carbon Black & CNFs & Graphene & Hierarchical Carbon Frame \\
\hline Si Source & Si NPs & a-Si & Si NPs & Si NPs \\
\hline Si Loading & $60 \%$ & $75 \%$ & $70 \%$ & $50 \%$ \\
\hline Initial Capacity $(\mathrm{mAh} / \mathrm{g})$ & $\sim 3000$ & $\sim 2000$ & $\sim 2300$ & $\sim 2000$ \\
\hline \multirow{2}{*}{ Cycling Performance $(\mathrm{mAh} / \mathrm{g})$} & $\sim 1500$ & $\sim 1500$ & $\sim 1700$ & $\sim 1600$ \\
& 22 cycles & 55 cycles & 120 cycles & 100 cycles \\
\hline
\end{tabular}

\section{Si and Graphene in Electrodes}

\subsection{Si Electrochemistry}

The properties of typical anode materials for LIB are summarized in Table 2. Si clearly outperforms on many fronts. However, despite decades of intensive study, a commercialized full cell with a Si anode providing desirable rate and cycling performance still remains challenging. There are serious consequences besides the physical structure collapse due to volume expansion resulted from lithiating of $\mathrm{Si}$, such as: (1) solid electrolyte interphase (SEI) layer becomes unstable after several cycles of lithiation and delithiation leading to short cycle life and pulverization; (2) active Si anode loses contact with conductive carbon and binder resulting in permanent capacity fading; and (3) Si anode performs poorly at high charging/discharging rate due to the low electron conductivity.

Table 2. Comparison of anode materials.

\begin{tabular}{cccc}
\hline Anode & Li Metal [26] & Graphite & Silicon \\
\hline Potential vs. Lithium & 0 & $\sim 0.15$ & $\sim 0.3$ \\
Theoretical Capacity (mAh/g) & 3860 & $372\left(\mathrm{LiC}_{6}\right)$ & $3578\left(\mathrm{Li1}_{5} \mathrm{Si}_{4}\right)$ \\
Typical Charging Rate & $1 \mathrm{C}$ & $>1 \mathrm{C}$ & $1 / 10 \mathrm{C}$ \\
Reported Cycle Life & 300 & $>1000$ & $100 \sim 200$ \\
Ion Storage Mechanism & Plating/Stripping & Insertion/Extraction & Alloying/De-alloying \\
Current status & Research & Commercialized & Research \\
\hline
\end{tabular}

Typical charging/discharging curves for first two cycles of Si anode are presented in Figure 2. There are four plateaus labeled as Equations (1)-(4) corresponding to the following reactions [27]:

$$
\begin{gathered}
\mathrm{Si} \text { (crystalline) }+x \mathrm{Li} \rightarrow\left(1-\frac{x}{y}\right) \mathrm{Si}+\frac{x}{y} \mathrm{Li}_{y} \mathrm{Si} \text { (amorphous) } \\
4 \mathrm{Li}_{y} \mathrm{Si} \text { (amorphous) }+(15-4 y) \mathrm{Li} \leftrightarrow \mathrm{Li}_{15} \mathrm{Si}_{4} \text { (crystalline) at } \mathrm{V}<60 \mathrm{mV} \\
\mathrm{Li}_{15} \mathrm{Si}_{4} \text { (crystalline) } \leftrightarrow 4 \mathrm{Li}_{y} \mathrm{Si} \text { (amorphous) }+(15-4 y) \mathrm{Li} \text { at } \mathrm{V}<60 \mathrm{mV} \\
\mathrm{Li}_{15} \mathrm{Si}_{4} \text { (amorphous) } \rightarrow 4 \mathrm{Si} \text { (amorphous) }+15 \mathrm{Li} \\
\mathrm{Si} \text { (amorphous) }+x \mathrm{Li} \rightarrow\left(1-\frac{x}{y}\right) \mathrm{Si} \text { (amorphous) }+\frac{x}{y} \mathrm{Li}_{y} \mathrm{Si} \text { (amorphous) }
\end{gathered}
$$

The first discharging reaction includes a process in which crystalline Si transfers into amorphous $\mathrm{Si}$ as confirmed by Chiang et al. [27]. When the Si-based anode undergoes the first constant current discharging, the potential drops rapidly from initial state of open circuit current down to around $0.1 \mathrm{~V}$ vs. $\mathrm{Li} / \mathrm{Li}^{+}$. Then a broad and flat plateau appears between $0.08 \mathrm{~V}$ and $0.12 \mathrm{~V} v \mathrm{vs} . \mathrm{Li} / \mathrm{Li}^{+}$, which indicates that the crystalline $\mathrm{Si}$ is under lithiating, and is transferring into amorphous $\mathrm{Li}_{y} \mathrm{Si}$ as shown in Equation (1). The full capacity of $\mathrm{Si}\left(3570 \mathrm{mAh} / \mathrm{g}, \mathrm{Li}_{15} \mathrm{Si}_{4}\right)$ can be reached when the potential drops to $0 \mathrm{~V}$ vs. $\mathrm{Li} / \mathrm{Li}^{+}$as the amorphous $\mathrm{Li}_{y} \mathrm{Si}$ transfers into crystalline $\mathrm{Li}_{15} \mathrm{Si}_{4}$ (Equation (2a)). 
This recrystallization begins at the potential of $60 \mathrm{mV}$ vs. $\mathrm{Li} / \mathrm{Li}^{+}$. During the first constant current charging process, the crystalline $\mathrm{Li}_{15} \mathrm{Si}_{4}$ breaks into small clusters of amorphous $\mathrm{Li}_{15} \mathrm{Si}_{4}$ as seen in Equation (2b). Then the chemical potential continuously increases up to about $0.4 \mathrm{~V} \mathrm{vs.} \mathrm{Li} / \mathrm{Li}^{+}$as crystalline $\mathrm{Li}_{15} \mathrm{Si}_{4}$ transfers into amorphous $\mathrm{Li}_{15} \mathrm{Si}_{4}$ gradually. At the potential of $0.4 \mathrm{~V} \mathrm{vs}$. $\mathrm{Li} / \mathrm{Li}^{+}$, amorphous $\mathrm{Si}$ is delithiated according to Equation (3) as indicated by a plateau. During the second constant current discharging, the potential drops to $\sim 0.3 \mathrm{~V} \mathrm{vs.} \mathrm{Li} / \mathrm{Li}^{+}$then reaches a plateau that is resulted from amorphous $\mathrm{Si}$ transferring into amorphous $\mathrm{Li}_{y} \mathrm{Si}$ (Equation (4)). At the end of the second discharging, the slope of plateau changes again because of the formation of crystalline $\mathrm{Li}_{15} \mathrm{Si}_{4}$ starting at potential of $60 \mathrm{mV}$ vs. $\mathrm{Li} / \mathrm{Li}^{+}$as seen in Equation (2a).

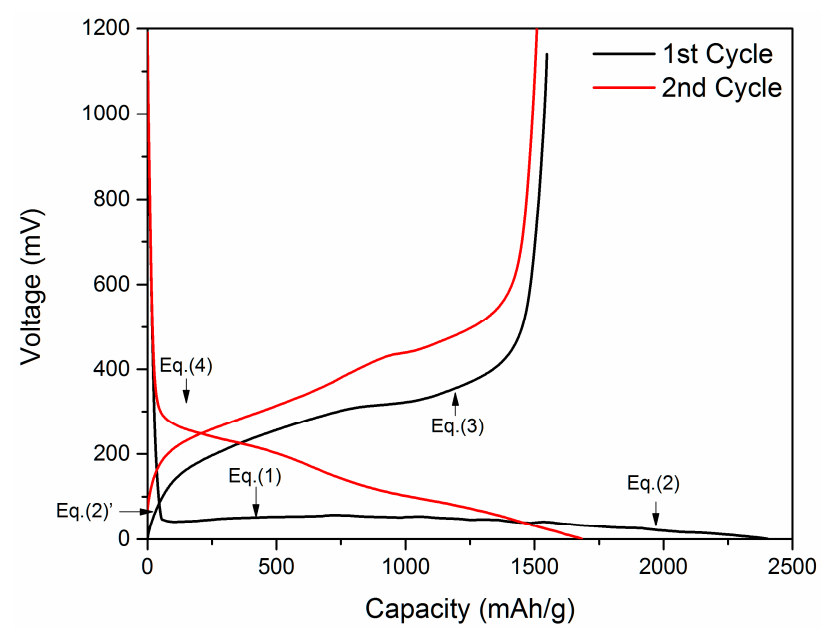

Figure 2. A typical charging/discharging curve for Si anode ( 100 nm Si electrode, Polyvinylidene fluoride (PVDF) and Carbon Black; weight ratio 7:2:1, no further modification).

Given Si's huge volume expansion during lithiation and its low electric conductivity, cracking of $\mathrm{Si}$ anode during cycling is the main issue that leads to battery failure. A Si thin film was used as the substrate to observe the cracking behavior during charging/discharging as reported by Wang et al. [28]. A large-area nano-textured silicon thin films (NTSTF) was prepared and the 1st lithiation process resulted in dendrite-like cracks on the surface. After the 1st delithiation process, the cracking remained visible by Scanning Electron Microscopy (SEM). Due to the stress generated by charging/discharging process, the thin film eventually peeled off from its substrate and completely lost electronic contact after about 10 cycles. Several coating materials including $\mathrm{Cu}, \mathrm{Al}_{2} \mathrm{O}_{3}$ and Ti were utilized with $2 \sim 5 \mathrm{~nm}$ thickness to restrain the cracks $[28,29]$ and each of them helped reduce the crack size, control the crack elongation and improve the electrochemical performance. These experiments agreed with the results from other coating methods, especially carbon coating.

\subsection{Graphene in Electrodes}

Carbon coating has been applied to improve conductivity and electrochemical performance in $\mathrm{Si} / \mathrm{C}$ composite anode since the 1990s [30]. Carbon coating is needed to provide good electric conductivity in $\mathrm{Si} / \mathrm{C}$ matrix. Traditional carbon coating methods include polymer decomposition [31], chemical/atomic deposition [32] and mechanical milling [33]. Two challenges persist in attempts to obtain long cycle life for Si anode. Firstly, due to the volume expansion and contraction of Si during lithiation/delithiation, pulverization happens and results in loose Si particles that stop participating in electrochemical reactions. Secondly, the solid electrolyte interphase (SEI) layer breaks during each charging cycle, and new SEI layers grow subsequently. This repetitive process consumes both $\mathrm{Si}$ and electrolyte. The traditional carbon coating on $\mathrm{Si}$ has not been able to sufficiently overcome these two challenges [34-36]. 
Thus, graphene was considered as an alternative carbon coating with the hope for graphene to retain intimate contact with Si nanoparticles before and after volume expansion, be electronically and ionically conductive, and be able to maintain stable SEI layers [37,38].

Graphene, a 2-D single layer of bonded carbon atoms was first synthesized by Novoselov and Geim in 2004 [39] through mechanical exfoliation method on bulk graphite flask. Graphene exhibited exceptional physical properties, such as high electrical conductivity $\left(10^{6} \mathrm{~S} / \mathrm{m}\right)[40,41]$, high thermal conductivity $(500 \sim 600 \mathrm{~W} /(\mathrm{m} \cdot \mathrm{K}))$ [42] and super stiffness $\left(1.1 \times 10^{3} \mathrm{GPa}\right.$ Young's Modulus) [40]. Its unique physical properties can be attributed to its $\mathrm{C}=\mathrm{C}$ resonance structure, hexagonally arranged $\mathrm{sp}^{2} \sigma$ bonding and $\pi$ electron. Several synthesis methods have been developed, including exfoliation of graphite [43,44], chemical vapor deposition (CVD) [45] and thermal/chemical reduce of graphite oxide (GO) [41,44]. The microstructure, chemical and physical properties of the graphene are highly dependent on their synthesis routines. For example, the micromechanical cleavage method (scotch tape method) yields high quality graphene mono-/bi-sheets with the least number of defects [46]; mono-layer graphene grown by CVD method on the $\mathrm{Cu}$ substrate could achieve up to $0.76 \mathrm{~m}$ in diagonal length which is suitable for field emission applications with good ohmic contact [47,48]; and graphene obtained by unzipping carbon nanotubes can create a band-gap which is different from the typical graphene with zero band-gap $[49,50]$.

Among all the methods, graphene synthesized by GO is commonly used in electrochemical devices such as photovoltaic cells, super capacitors and LIBs [51-53]. The GO reduction is a process of low cost, simplicity and relatively high yield. The process enables functionalization of the graphene to provide specific properties demanded by certain applications. Although how graphene acts in composite electrodes has not been fully investigated, graphene is typically considered as not reactive with most of the current electrodes, electrolyte, and separator materials [54]. For example, a direct electron transfer glucose biosensor fabricated by self-assembling of glucose oxidase and reduced carboxyl graphene exhibited a linear response to glucose concentrations; A three-dimensional hierarchical architecture Li/S battery was achieved by sandwiching multiwall carbon nanotube/sulfur (MWCNT@S) composite with amine functional graphene nanosheets [55].

Graphene can serve either as an electrode material or an additive material in LIBs. Until the cost of synthesizing graphene becomes more affordable, the use of graphene as additive material seems to be applicable. The improvement of electrochemical performance as a result of adding graphene has been reported in many anode materials such as carbon based graphene composite, metal oxide/graphene composite and alloy with graphene [56-59].

\section{Si/Graphene Anodes}

A summary of reported studies on $\mathrm{Si} /$ Graphene nanocomposites is provided in Table 3 with unified units in current rate and capacity; this is discussed in the following sections. 
Table 3. A summary of studies on $\mathrm{Si} /$ Graphene nanocomposites anodes.

\begin{tabular}{|c|c|c|c|c|c|c|c|}
\hline Si Source & Graphene Synthesis Method & $\begin{array}{l}\text { Graphene } \\
\text { Weight Ratio }\end{array}$ & $\begin{array}{c}\text { Electrode } \\
\text { Loading Density } \\
\left(\mathrm{mg} / \mathrm{cm}^{2}\right)\end{array}$ & $\begin{array}{l}\text { Initial Reversible } \\
\text { Capacity (mAh/g) }\end{array}$ & $\begin{array}{l}\text { First Cycle } \\
\text { Efficiency }\end{array}$ & $\begin{array}{l}\text { Best Capacity Retention } \\
\text { with Current Rate }\end{array}$ & $\begin{array}{l}\text { Ref. with Similar } \\
\text { Si/Graphene } \\
\text { Structure }\end{array}$ \\
\hline Si NPs & Graphite Oxidation + Thermal Reduction & $\sim 40 \%$ & 2 & $\sim 2050$ & $\sim 96 \%$ & $300 \mathrm{th}, \sim 56 \%, 1000 \mathrm{~mA} / \mathrm{g}$ & {$[23,60]$} \\
\hline Si NPs & $\begin{array}{l}\text { Modified Hummers Method }+ \text { Chemical } \\
\text { Reduction }\end{array}$ & $73.6 \%$ & NR & $\sim 1000$ & $\sim 41 \%$ & $100 \mathrm{th}, \sim 70.8 \%, 50 \mathrm{~mA} / \mathrm{g}$ & {$[61,62]$} \\
\hline Si NPs & Hummers Method + Thermal Reduction & $66.7 \%$ & NR & 1040 & $63 \%$ & 30th, $94 \%, 50 \mathrm{~mA} / \mathrm{g}$ & [63-67] \\
\hline Si NPs & Thermal Expansion & $\sim 33 \%$ & NR & 2753 & $\sim 80 \%$ & 30th, $\sim 91 \%, 300 \mathrm{~mA} / \mathrm{g}$ & {$[68,69]$} \\
\hline $\begin{array}{l}\text { Aerosol Droplets } \\
\text { Si NPs }\end{array}$ & Crumpled Reduction & $40 \%$ & 0.2 & 1175 & $\sim 95 \%$ & 250th, $\sim 86 \%, 1000 \mathrm{~mA} / \mathrm{g}$ & {$[70,71]$} \\
\hline $\begin{array}{l}\text { 3-D Porous Si by } \\
\text { Magnesiothermic }\end{array}$ & Hummers Method + Thermal Reduction & $\sim 40 \%$ & NR & 1100 & $\sim 79 \%$ & $100 \mathrm{th}, \sim 50 \%, 5000 \mathrm{~mA} / \mathrm{g}$ & [72-76] \\
\hline $\begin{array}{l}\text { Si NPs on } \\
\text { graphite Foam }\end{array}$ & Hummers Method + Thermal Reduction & $15.1 \%$ & 1.5 & 1000 & $62.5 \%$ & $100 \mathrm{th}, \sim 37 \%, 400 \mathrm{~mA} / \mathrm{g}$ & [77] \\
\hline $\begin{array}{l}\text { Si NPs on 3-D } \\
\text { tree-like GNS }\end{array}$ & Microwave Plasma CVD & $19 \%$ & NR & 2731 & $\sim 56 \%$ & 160 th, $\sim 67 \%, 150 \mathrm{~mA} / \mathrm{g}$ & [78] \\
\hline (PANI)-Si NPs & $\begin{array}{l}\text { Modified Hummers Method + Pyrolysis } \\
\text { Method }\end{array}$ & $26 \%$ & 0.3 & $\sim 1500$ & $\sim 70 \%$ & 300th, $\sim 76 \%, 2000 \mathrm{~mA} / \mathrm{g}$ & [79] \\
\hline $\begin{array}{c}\text { Si NPs on } \\
\text { Electrospunn CNFs }\end{array}$ & Chemical Method + Thermal Reduction & $0.6 \%$ & NR & 1270 & $71.2 \%$ & 50 th, $\sim 91 \%, 100 \mathrm{~mA} / \mathrm{g}$ & {$[80]$} \\
\hline $\begin{array}{c}\text { Si NPs on } \\
\text { Graphene Hydrogel }\end{array}$ & $\begin{array}{l}\text { Modified Hummers Method Ascorbic Acid + } \\
\text { Thermal Reduction }\end{array}$ & $29 \%$ & NR & 2250 & $53 \%$ & 150 th, $\sim 50 \%, 100 \mathrm{~mA} / \mathrm{g}$ & [81] \\
\hline 3D Si NWs & CVD + Plasma enhanced CVD & NR & $\sim 0.5$ & $\sim 2600$ & $97 \%$ & $100 \mathrm{th}, \sim 29 \%, 500 \mathrm{~mA} / \mathrm{g}$ & [82] \\
\hline
\end{tabular}




\subsection{Various Synthesis Methods to Form Si/Graphene Composite Anode}

After the successful demonstration of graphene supported $\mathrm{SnO}_{2}$ nanoparticles (NPs) as LIB anode [58], Kung et al. was the first group to report Si NPs-graphene composites for LIB anodes in the year 2010 [23]. In this study, Si NPs with particle size less than $30 \mathrm{~nm}$ were pre-treated in air overnight to ensure the formation of silicon oxide layer on the surface and then mixed with graphene oxide (GO) synthesized by graphite oxidization. The mixture was reduced by $10 \% \mathrm{H}_{2}$ in Ar at elevated temperature to form the Si/Graphene nanocomposites. The as-fabricated Si/Graphene nanocomposites exhibited a capacity of approximately $1950 \mathrm{mAh} / \mathrm{g}$ in the first discharging process and about $900 \mathrm{mAh} / \mathrm{g}$ capacity retention after 120 cycles at a current rate of $1000 \mathrm{~mA} / \mathrm{g}$ [23]. Later, Wang et al. demonstrated a free-standing graphene-Si composite film with graphene reduced by Hydrazine at mild elevated temperature $\left(80^{\circ} \mathrm{C}\right)$ and the Si particle size ranged from 3 to $80 \mathrm{~nm}$ [61]. It showed an excellent cycling performance with only $3 \%$ capacity loss from the fifth cycle $(\sim 820 \mathrm{mAh} / \mathrm{g})$ to the 100 th cycle $(\sim 800 \mathrm{mAh} / \mathrm{g})$. Besides the Si NPs, there were other forms of Si/Graphene composites. Yan et al. were able to grow Si nanowires (SNWs) on graphene surface by using Au NPs as catalysts. This study reported an initial capacity of $\sim 3500 \mathrm{mAh} / \mathrm{g}$ and a cycling performance of above $1500 \mathrm{mAh} / \mathrm{g}$ after 30 cycles at the current rate of $420 \mathrm{~mA} / \mathrm{g}$ [83]. Liu and Zhu et al. fabricated a 3-D porous architecture of $\mathrm{Si} / G r a p h e n e$ nanocomposite where 3-D Si was synthesized by the Magnesiothermic Reduction method. This 3-D porous $\mathrm{Si} / G r a p h e n e$ nanocomposite demonstrated a capacity retention of more than $400 \mathrm{mAh} / \mathrm{g}$ at the high current rate of $5000 \mathrm{~mA} / \mathrm{g}$ after 100 cycles [72]. In these pioneer studies, the preparation of $\mathrm{Si} / G r a p h e n e$ nanocomposites relied on dispersion, mixing and catalyst-assisted growth. The electrochemical performance of those nanocomposites depended highly on dispersion of nanostructured $\mathrm{Si}$ and large graphene loading (more than $30 \mathrm{wt} \%$ as shown in Table 3).

In 2012, Huang et al. used evaporation-induced capillary force to wrap graphene sheets around the Si NPs, where graphene was heavily crumpled to form the shell structure. Though the weight ratio of graphene was high (40 wt \%), it was the first attempt to form capsulated Si NPs with graphene. This crumpled graphene-Si nanocomposite showed an initial capacity of $1175 \mathrm{mAh} / \mathrm{g}$ and $86 \%$ capacity retention after 250 cycles. The crumpled graphene structure was believed to help accommodate the expansion/contraction of encapsulated Si without fracture [70]. In 2013, Ji and Ruoff et al. fabricated a graphene-encapsulated Si on Ultrathin-Graphite Foam (UGF) for LIB anode. In their work, Si NPs were first modified by poly(diallyldimethylammonium chloride) (PDDA) to have graphene oxide (GO) wrapping. The resulted Si/GO NPs were then drop-casted on UGF surface, followed with a thermal annealing process to obtain $\mathrm{Si} / \mathrm{Graphene} \mathrm{NPs}$ on UGF. The initial capacity of $\mathrm{Si} /$ Graphene NPs on UGF was around $1000 \mathrm{mAh} / \mathrm{g}$ and the retained capacity was above $400 \mathrm{mAh} / \mathrm{g}$ after 100 cycles at the current rate of $400 \mathrm{~mA} / \mathrm{g}$ [77]. Li and Zhi et al. demonstrated a self-supporting binder-free Si based anode by encapsulation of Si NWs with dual adaptable apparels. First, overlapped graphene sheets were grown from Si NWs by the Chemical Vapor Deposition (CVD) method to form Si NWs@G nanocables. The resulted powders were dispersed in graphene oxide aqueous solution before vacuum filtration. Finally, the graphene oxide was reduced to obtain SiNWs@graphene@reduced-graphene-oxide structure for accommodation of volume expansion during lithiation. Scanning transmission electron microscopy (STEM) did not identify any loose Si clusters in this composite after initial lithiation process. The fabricated SiNWs@graphene@reduced-graphene-oxide composite demonstrated excellent high rate cycling performance. It had a $>95 \%$ capacity retention for 50 cycles at the current rate of $840 \mathrm{~mA} / \mathrm{g}$ and $>90 \%$ capacity retention for 100 cycles at the current rate of $2100 \mathrm{~mA} / \mathrm{g}$ [84].

Another technique to fabricate $\mathrm{Si} / G$ raphene nanocomposite was pyrolysis that began with freeze-drying of $\mathrm{Si} / \mathrm{GO}$ suspensions. After the pyrolysis process, $\mathrm{GO}$ reduction at elevated temperature was needed to obtain sandwiched $\mathrm{Si} / \mathrm{Graphene}[65,79]$. When the loading ratio of Si NPs and graphene was 1:2, the composites demonstrated good cycling performance. The capacity at the 200th cycle was $\sim 600 \mathrm{mAh} / \mathrm{g}$ (96\% initial capacity retention). 


\subsection{Composition of Si/Graphene Composite Anode}

Many studies focused on the synthesizing method of $\mathrm{Si} /$ Graphene anode and used high graphene ratio $(>20 \mathrm{wt} \%)[65,75,80]$. The effect of increased graphene weight ratio in Si/Graphene nanocomposite was investigated by Hwang et al. Si/Graphene with weight ratio of 3:1, 2:1, 1:1 and 1:2 were studied. The $\mathrm{Si} /$ graphene with ratio of 3:1 demonstrated the best balance on both initial capacity and cycling performance [75]. Chabot et al. also investigated the loading ratio between Si NPs and graphene. Si/Graphene nanocomposites with ratio of 1:3, 1:2, 1:1 and 1:0.5 were studied. Si/Graphene with ratio of 1:0.5 had the highest initial capacity of $\sim 2600 \mathrm{mAh} / \mathrm{g}$. However, Si/Graphene with ratio of 1:1 exhibited the highest retention capacity of $\sim 1000 \mathrm{mAh} / \mathrm{g}$ after 100 cycles [65].

The electrode loading density is also very important since it could impact the whole cell energy density [85,86]. A loading density of $2.5 \sim 3.5 \mathrm{mAh} / \mathrm{cm}^{2}$ (equal to $\sim 1 \mathrm{mg} / \mathrm{cm}^{2}$ of Si anode) is the minimum requirement in the traditional full cells, and a $7 \sim 10 \mathrm{mg} / \mathrm{cm}^{2}$ loading density is desirable for high energy density battery applications $[87,88]$. Low loading density of the anode undesirably increases the total weight of the full cell and brings down the overall energy density, which is unfavorable for electric vehicles (EVs) [89]. As seen in Table 3, many of the published reports did not reveal the electrode loading density data. Only a couple of studies reported loading densities meeting the requirement for commercial full cells. Ji and Ruoff et al. demonstrated a graphene-encapsulated Si on ultrathin-graphite foam (UGF) anode with electrode loading density of $1.5 \mathrm{mg} / \mathrm{cm}^{2}$. The overall initial capacity of the Si/Graphene/UGF electrode was $983 \mathrm{mAh} / \mathrm{g}$, and the retained capacity at 100th cycle was $370 \mathrm{mAh} / \mathrm{g}$ [77]. Kung fabricated Si nanoparticles-graphene paper composite anode with electrode loading density of $2 \mathrm{mg} / \mathrm{cm}^{2}$. An initial capacity of $\sim 2000 \mathrm{mAh} / \mathrm{g}$ was achieved with cycling performance of $\sim 1500 \mathrm{mAh} / \mathrm{g}$ at the 300th cycle [23].

\subsection{Graphene Quality}

It is well established that the quality of graphene highly depends on the synthesis conditions when fabricated by reduction of GO. For example, the history of thermal process in Hummers' method heavily impacted the defect density in graphene nanosheets $[90,91]$. Some et al. obtained Nitrogen/Sulphur-impurity-free graphene by thiophene template-assist chemical reduction with thermal healing process [92]. Our previous work demonstrated that the quality of synthesized graphene nanosheets was strongly dependent on the processing conditions [93]. However, the effect of graphene quality on the performance of battery electrodes has yet to be investigated systematically.

SEM was typically the first option for most scientists to observe the morphology of Si/Graphene composites. However, the thickness and number of layers of Graphene cannot be identified due to the limitation of SEM imaging. For example, a crumple surface of graphene sheet was visualized by SEM $[89,94]$. It was speculated that the winkled surface morphology indicated a relatively high surface area of graphene and contributed to the increase in electron conductivity, which resulted in an improved electrochemical performance [70,95]. The transmission electron microscope (TEM) was applied to investigate the crystal structure of Si/Graphene nanocomposites. By adjusting the contract of TEM image, graphene sheet can be isolated from the $\mathrm{Si} / \mathrm{Graphene}$ nanocomposites due to its thin thickness and light atomic weight. The atomic force microscope (AFM) was utilized to measure the thickness of graphene nanosheets. Many of the fabricated Si/Graphene nanocomposites had graphene thickness of less than $10 \mathrm{~nm}[23,83,94]$. However, AFM was not able to tell if the graphene was single layer due to molecules absorbed on the graphene surface.

Raman spectrum was efficient to provide additional information about the quality of the synthesized graphene nanosheet/nanosheets [95-97]. It had been well established that graphite and graphene have characteristic peaks at $1340 \mathrm{~cm}^{-1}, 1584 \mathrm{~cm}^{-1}$ and $2700 \mathrm{~cm}^{-1}$ as shown in Figure 3 . The peak at $1340 \mathrm{~cm}^{-1}$ was characterized as D band. The peak at $1584 \mathrm{~cm}^{-1}$ was called $\mathrm{G}$ band, which was caused by $E_{2 g}$ vibration mode that represented the $C=C$ bond stretching of all pairs of $s^{2}$ atoms. The peak at $2700 \mathrm{~cm}^{-1}$ was characterized as $\mathrm{G}^{\prime}(2 \mathrm{D})$ band, which was caused by the double resonance process. The positions of both $G$ and $G^{\prime}$ bands could determine the number of layers of 
graphene nanosheets. For a single graphene, the peak position would have $5 \mathrm{~cm}^{-1}$ upshifting with constant intensity. The $G^{\prime}$ band was also named $2 \mathrm{D}$ band because the $\mathrm{G}^{\prime}$ peak would follow the movement of $\mathrm{D}$ peak with a correlated number of layers of graphene nanosheets. There were actually two individual peaks identified within the $2 \mathrm{D}$ band, which were $2 \mathrm{D}_{1}$ and $2 \mathrm{D}_{2}$ in graphite, but only $2 \mathrm{D}_{1}$ could be observed in single layer graphene. The intensity of $2 \mathrm{D}_{2}$ peak increased with the increasing number of graphene layers. The 2D peak eventually grew into the typical graphite characteristic peaks when there were more than five layers of graphene nanosheets stacked together [96,98]. The Raman spectrum could also provide information about the size of graphene flakes and defect density by calculating the intensity ratio of $\mathrm{D}$ band and $\mathrm{G}$ band $\left(\mathrm{I}_{\mathrm{D}} / \mathrm{I}_{\mathrm{G}}\right)$, where $\mathrm{I}_{\mathrm{D}}$ and $\mathrm{I}_{\mathrm{G}}$ represented the integrated intensities [99,100].

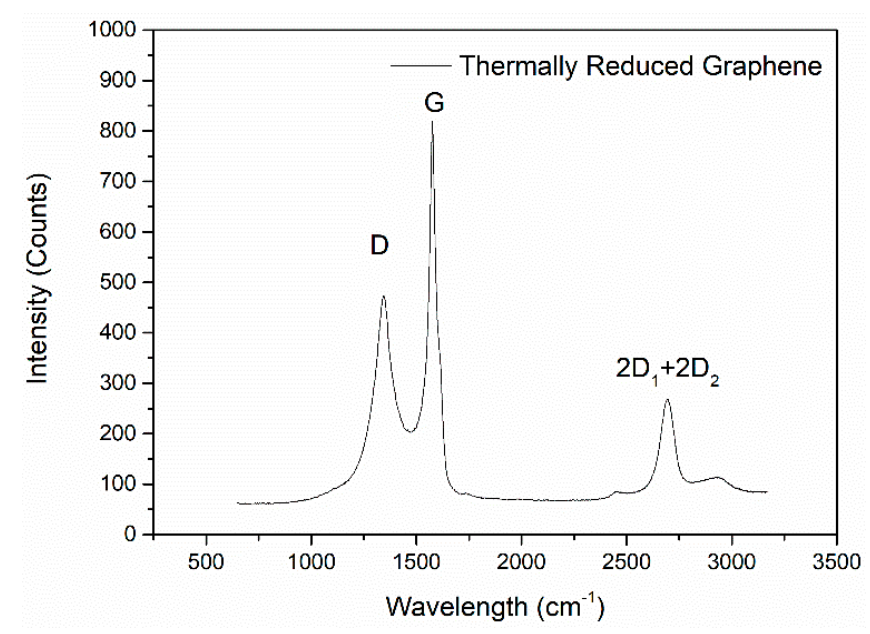

Figure 3. Example Raman spectrum of a thermally reduced graphene (by Hummer's Method).

Even though studies on Si/Graphene composites routinely utilize SEM, TEM, AFM and Raman, no systematic study has been found that investigates how the quality of Graphene impacted electrochemical performance. In the study of applications such as bioelectric sensors, optical electronics and photovoltaic cells, it was discovered that single or mono layer, large, flat and defect-free structures were desirable for these applications [51,101,102]. Battery electrodes may demand a different set of qualities.

There are a lot of variables in the Si/Graphene nanocomposites, including variables concerning $\mathrm{Si}$ (morphology, synthesis routine, and the dimensions), variables concerning graphene nanosheets (graphene synthesis routine) and variables in assembly methods (direct mixing, chemical bonding, and physical attraction). Due to the large variation in synthesizing conditions and lack of complete information, comparative study to identify desirable properties of graphene for Si/Graphene composite anodes based solely on literature study is not feasible. It is critical to isolate certain properties as was done in some preliminary work by Cen and Liang et al. In this work, Si nanoparticle size and surface treatment were maintained constant while the graphene properties were varied by different graphene oxide reduction conditions [103].

\section{Conclusions}

When $\mathrm{Si}$ is used as the anode, carbon coating is needed. Si/Graphene nanocomposites are considered one of the most promising anode materials for next generation high energy density LIBs. Many studies have explored various synthesis methods to form $\mathrm{Si} / \mathrm{Graphene}$ composite anodes. Currently, the following challenges remain: (1) high cost of synthesizing nano-sized Si and graphene nanosheets; (2) low electrode loading weight; (3) still unsatisfied cycling performance due to volume 
expansion. The quality of carbon materials employed in $\mathrm{Si} / \mathrm{C}$ composites affects the electrochemical performance of the resulted anode and needs to be understood.

Acknowledgments: No external funding was used in this study. The publication cost in open access was waived by the journal C (ISSN 2311-5629, http://www.mdpi.com/journal/carbon).

Author Contributions: Yinjie Cen conducted the literature review under guidance of Qingwei Qin, Richard D. Sisson and Jianyu Liang. The four authors collaborated on writing the manuscript.

Conflicts of Interest: The authors declare no conflict of interest.

\section{References}

1. Tawfik, H.; Hung, Y.; Mahajan, D. Metal bipolar plates for PEM fuel cell-A review. J. Power Sources 2007, 163, 755-767. [CrossRef]

2. Mei, A.; Li, X.; Liu, L.; Ku, Z.; Liu, T.; Rong, Y.; Xu, M.; Hu, M.; Chen, J.; Yang, Y. A hole-conductor-free, fully printable mesoscopic perovskite solar cell with high stability. Science 2014, 345, 295-298. [CrossRef] [PubMed]

3. Yoshio, M.; Wang, H.; Fukuda, K.; Hara, Y.; Adachi, Y. Effect of Carbon Coating on Electrochemical Performance of Treated Natural Graphite as Lithium-Ion Battery Anode Material. J. Electrochem. Soc. 2000, 147, 1245-1250. [CrossRef]

4. Tsumura, T.; Kojitani, N.; Izumi, I.; Iwashita, N.; Toyoda, M.; Inagaki, M. Carbon coating of anatase-type $\mathrm{TiO}_{2}$ and photoactivity. J. Mater. Chem. 2002, 12, 1391-1396. [CrossRef]

5. Yang, W.; Araki, H.; Tang, C.; Thaveethavorn, S.; Kohyama, A.; Suzuki, H.; Noda, T. Single-Crystal SiC Nanowires with a Thin Carbon Coating for Stronger and Tougher Ceramic Composites. Adv. Mater. 2005, 17, 1519-1523. [CrossRef]

6. Show, Y. Electrically conductive amorphous carbon coating on metal bipolar plates for PEFC. Surf. Coat. Technol. 2007, 202, 1252-1255. [CrossRef]

7. Nagaura, T.; Tozawa, K. Lithium ion rechargeable battery. Prog. Batter. Sol. Cells 1990, 9, 209.

8. Padhi, A.K.; Nanjundaswamy, K.S.; Goodenough, J.B. Phospho-olivines as positive-electrode materials for rechargeable lithium batteries. J. Electrochem. Soc. 1997, 144, 1188-1194. [CrossRef]

9. Etacheri, V.; Marom, R.; Elazari, R.; Salitra, G.; Aurbach, D. Challenges in the development of advanced Li-ion batteries: A review. Energy Environ. Sci. 2011, 4, 3243-3262. [CrossRef]

10. Ji, L.W.; Lin, Z.; Alcoutlabi, M.; Zhang, X.W. Recent developments in nanostructured anode materials for rechargeable lithium-ion batteries. Energy Environ. Sci. 2011, 4, 2682-2699. [CrossRef]

11. Goodenough, J.B.; Park, K.-S. The Li-ion rechargeable battery: A perspective. J. Am. Chem. Soc. 2013, 135, 1167-1176. [CrossRef] [PubMed]

12. Thackeray, M.M.; Wolverton, C.; Isaacs, E.D. Electrical energy storage for transportation-Approaching the limits of, and going beyond, lithium-ion batteries. Energy Environ. Sci. 2012, 5, 7854-7863. [CrossRef]

13. Shi, H.; Barker, J.; Saidi, M.Y.; Koksbang, R. Structure and lithium intercalation properties of synthetic and natural graphite. J. Electrochem. Soc. 1996, 143, 3466-3472. [CrossRef]

14. Weydanz, W.; Wohlfahrt-Mehrens, M.; Huggins, R.A. A room temperature study of the binary lithium-silicon and the ternary lithium-chromium-silicon system for use in rechargeable lithium batteries. J. Power Sources 1999, 81, 237-242. [CrossRef]

15. Li, H.; Huang, X.; Chen, L.; Wu, Z.; Liang, Y. A high capacity nano Si composite anode material for lithium rechargeable batteries. Electrochem. Solid-State Lett. 1999, 2, 547-549. [CrossRef]

16. Huggins, R.A. Lithium alloy negative electrodes. J. Power Sources 1999, 81, 13-19. [CrossRef]

17. Reece, S.Y.; Hamel, J.A.; Sung, K.; Jarvi, T.D.; Esswein, A.J.; Pijpers, J.J.; Nocera, D.G. Wireless solar water splitting using silicon-based semiconductors and earth-abundant catalysts. Science 2011, 334, 645-648. [CrossRef] [PubMed]

18. Obrovac, M.; Christensen, L. Structural changes in silicon anodes during lithium insertion/extraction. Electrochem. Solid-State Lett. 2004, 7, A93-A96. [CrossRef]

19. Wang, G.; Ahn, J.; Yao, J.; Bewlay, S.; Liu, H. Nanostructured Si-C composite anodes for lithium-ion batteries. Electrochem. Commun. 2004, 6, 689-692. [CrossRef] 
20. Wu, H.; Chan, G.; Choi, J.W.; Ryu, I.; Yao, Y.; McDowell, M.T.; Lee, S.W.; Jackson, A.; Yang, Y.; Hu, L. Stable cycling of double-walled silicon nanotube battery anodes through solid-electrolyte interphase control. Nat. Nanotechnol. 2012, 7, 310. [CrossRef] [PubMed]

21. Cui, L.F.; Yang, Y.; Hsu, C.M.; Cui, Y. Carbon-Silicon Core-Shell Nanowires as High Capacity Electrode for Lithium Ion Batteries. Nano Lett. 2009, 9, 3370-3374. [CrossRef] [PubMed]

22. Wen, Y.; Zhu, Y.; Langrock, A.; Manivannan, A.; Ehrman, S.H.; Wang, C. Graphene-Bonded and-Encapsulated Si Nanoparticles for Lithium Ion Battery Anodes. Small 2013, 9, 2810-2816. [CrossRef] [PubMed]

23. Lee, J.K.; Smith, K.B.; Hayner, C.M.; Kung, H.H. Silicon nanoparticles-graphene paper composites for Li ion battery anodes. Chem. Commun. (Camb.) 2010, 46, 2025-2027. [CrossRef] [PubMed]

24. Ge, M.; Rong, J.; Fang, X.; Zhou, C. Porous doped silicon nanowires for lithium ion battery anode with long cycle life. Nano Lett. 2012, 12, 2318-2323. [CrossRef] [PubMed]

25. Magasinski, A.; Dixon, P.; Hertzberg, B.; Kvit, A.; Ayala, J.; Yushin, G. High-performance lithium-ion anodes using a hierarchical bottom-up approach. Nat. Mater. 2010, 9, 353-358. [CrossRef] [PubMed]

26. Lin, D.; Liu, Y.; Cui, Y. Reviving the lithium metal anode for high-energy batteries. Nat. Nanotechnol. 2017, 12, 194. [CrossRef] [PubMed]

27. Limthongkul, P.; Jang, Y.-I.; Dudney, N.J.; Chiang, Y.-M. Electrochemically-driven solid-state amorphization in lithium-silicon alloys and implications for lithium storage. Acta Mater. 2003, 51, 1103-1113. [CrossRef]

28. Wang, Y.; Liu, Y.; Zheng, J.; Zheng, H.; Mei, Z.; Du, X.; Li, H. Electrochemical performances and volume variation of nano-textured silicon thin films as anodes for lithium-ion batteries. Nanotechnology 2013, 24, 424011. [CrossRef] [PubMed]

29. Wang, Y.; He, Y.; Xiao, R.; Li, H.; Aifantis, K.E.; Huang, X. Investigation of crack patterns and cyclic performance of Ti-Si nanocomposite thin film anodes for lithium ion batteries. J. Power Sources 2012, 202, 236-245. [CrossRef]

30. Kasavajjula, U.; Wang, C.; Appleby, A.J. Nano-and bulk-silicon-based insertion anodes for lithium-ion secondary cells. J. Power Sources 2007, 163, 1003-1039. [CrossRef]

31. Guo, Z.; Milin, E.; Wang, J.; Chen, J.; Liu, H.-K. Silicon/disordered carbon nanocomposites for lithium-ion battery anodes. J. Electrochem. Soc. 2005, 152, A2211-A2216. [CrossRef]

32. Ng, S.H.; Wang, J.; Wexler, D.; Chew, S.Y.; Liu, H.K. Amorphous carbon-coated silicon nanocomposites: A low-temperature synthesis via spray pyrolysis and their application as high-capacity anodes for lithium-ion batteries. J. Phys. Chem. C 2007, 111, 11131-11138. [CrossRef]

33. Wang, D.; Gao, M.; Pan, H.; Wang, J.; Liu, Y. High performance amorphous-Si@SiOx/C composite anode materials for Li-ion batteries derived from ball-milling and in situ carbonization. J. Power Sources 2014, 256, 190-199. [CrossRef]

34. Ryu, J.H.; Kim, J.W.; Sung, Y.-E.; Oh, S.M. Failure modes of silicon powder negative electrode in lithium secondary batteries. Electrochem. Solid-State Lett. 2004, 7, A306-A309. [CrossRef]

35. Radvanyi, E.; Porcher, W.; De Vito, E.; Montani, A.; Franger, S.; Larbi, S.J.S. Failure mechanisms of nano-silicon anodes upon cycling: An electrode porosity evolution model. Phys. Chem. Chem. Phys. 2014, 16, 17142-17153. [CrossRef] [PubMed]

36. Oumellal, Y.; Delpuech, N.; Mazouzi, D.; Dupre, N.; Gaubicher, J.; Moreau, P.; Soudan, P.; Lestriez, B.; Guyomard, D. The failure mechanism of nano-sized Si-based negative electrodes for lithium ion batteries. J. Mater. Chem. 2011, 21, 6201-6208. [CrossRef]

37. Luo, F.; Liu, B.; Zheng, J.; Chu, G.; Zhong, K.; Li, H.; Huang, X.; Chen, L. Review-Nano-Silicon/Carbon Composite Anode Materials Towards Practical Application for Next Generation Li-Ion Batteries. J. Electrochem. Soc. 2015, 162, A2509-A2528. [CrossRef]

38. Lee, K.T.; Cho, J. Roles of nanosize in lithium reactive nanomaterials for lithium ion batteries. Nano Today 2011, 6, 28-41. [CrossRef]

39. Novoselov, K.S.; Geim, A.K.; Morozov, S.; Jiang, D.; Zhang, Y.; Dubonos, S.A.; Grigorieva, I.; Firsov, A. Electric field effect in atomically thin carbon films. Science 2004, 306, 666-669. [CrossRef] [PubMed]

40. Chen, H.; Müller, M.B.; Gilmore, K.J.; Wallace, G.G.; Li, D. Mechanically strong, electrically conductive, and biocompatible graphene paper. Adv. Mater. 2008, 20, 3557-3561. [CrossRef]

41. Stankovich, S.; Dikin, D.A.; Piner, R.D.; Kohlhaas, K.A.; Kleinhammes, A.; Jia, Y.; Wu, Y.; Nguyen, S.T.; Ruoff, R.S. Synthesis of graphene-based nanosheets via chemical reduction of exfoliated graphite oxide. Carbon 2007, 45, 1558-1565. [CrossRef] 
42. Balandin, A.A.; Ghosh, S.; Bao, W.; Calizo, I.; Teweldebrhan, D.; Miao, F.; Lau, C.N. Superior thermal conductivity of single-layer graphene. Nano Lett. 2008, 8, 902-907. [CrossRef] [PubMed]

43. Zhao, W.; Fang, M.; Wu, F.; Wu, H.; Wang, L.; Chen, G. Preparation of graphene by exfoliation of graphite using wet ball milling. J. Mater. Chem. 2010, 20, 5817-5819. [CrossRef]

44. Cai, M.; Thorpe, D.; Adamson, D.H.; Schniepp, H.C. Methods of graphite exfoliation. J. Mater. Chem. 2012, 22, 24992-25002. [CrossRef]

45. Losurdo, M.; Giangregorio, M.M.; Capezzuto, P.; Bruno, G. Graphene CVD growth on copper and nickel: Role of hydrogen in kinetics and structure. Phys. Chem. Chem. Phys. 2011, 13, 20836-20843. [CrossRef] [PubMed]

46. Edwards, R.S.; Coleman, K.S. Graphene synthesis: Relationship to applications. Nanoscale 2013, 5, 38-51. [CrossRef] [PubMed]

47. Bae, S.; Kim, H.; Lee, Y.; Xu, X.; Park, J.-S.; Zheng, Y.; Balakrishnan, J.; Lei, T.; Ri Kim, H.; Song, Y.I.; et al. Roll-to-roll production of 30-inch graphene films for transparent electrodes. Nat. Nanotechnol. 2010, 5, 574. [CrossRef] [PubMed]

48. Choi, W.; Lahiri, I.; Seelaboyina, R.; Kang, Y.S. Synthesis of Graphene and Its Applications: A Review. Crit. Rev. Solid State Mater. Sci. 2010, 35, 52-71. [CrossRef]

49. Katsnelson, M.I. Graphene: Carbon in two dimensions. Mater. Today 2007, 10, 20-27. [CrossRef]

50. Zhang, Y.; Tang, T.-T.; Girit, C.; Hao, Z.; Martin, M.C.; Zettl, A.; Crommie, M.F.; Shen, Y.R.; Wang, F. Direct observation of a widely tunable bandgap in bilayer graphene. Nature 2009, 459, 820. [CrossRef] [PubMed]

51. Guo, C.X.; Yang, H.B.; Sheng, Z.M.; Lu, Z.S.; Song, Q.L.; Li, C.M. Layered graphene/quantum dots for photovoltaic devices. Angew. Chem. Int. Ed. 2010, 49, 3014-3017. [CrossRef] [PubMed]

52. Zhang, L.L.; Zhao, S.Y.; Tian, X.N.; Zhao, X.S. Layered Graphene Oxide Nanostructures with Sandwiched Conducting Polymers as Supercapacitor Electrodes. Langmuir 2010, 26, 17624-17628. [CrossRef] [PubMed]

53. Yoo, E.; Kim, J.; Hosono, E.; Zhou, H.; Kudo, T.; Honma, I. Large reversible Li storage of graphene nanosheet families for use in rechargeable lithium ion batteries. Nano Lett. 2008, 8, 2277-2282. [CrossRef] [PubMed]

54. Goriparti, S.; Miele, E.; De Angelis, F.; Di Fabrizio, E.; Zaccaria, R.P.; Capiglia, C. Review on recent progress of nanostructured anode materials for Li-ion batteries. J. Power Sources 2014, 257, 421-443. [CrossRef]

55. Chen, R.; Zhao, T.; Lu, J.; Wu, F.; Li, L.; Chen, J.; Tan, G.; Ye, Y.; Amine, K. Graphene-based three-dimensional hierarchical sandwich-type architecture for high-performance Li/S batteries. Nano Lett. 2013, 13, 4642-4649. [CrossRef] [PubMed]

56. Stankovich, S.; Piner, R.D.; Chen, X.; Wu, N.; Nguyen, S.T.; Ruoff, R.S. Stable aqueous dispersions of graphitic nanoplatelets via the reduction of exfoliated graphite oxide in the presence of poly(sodium 4-styrenesulfonate). J. Mater. Chem. 2006, 16, 155-158. [CrossRef]

57. Cen, Y.; Yao, Y.; Xu, Q.; Xia, Z.; Sisson, R.D.; Liang, J. Fabrication of $\mathrm{TiO}_{2}$-graphene composite for the enhanced performance of lithium batteries. RSC Adv. 2016, 6, 66971-66977. [CrossRef]

58. Paek, S.-M.; Yoo, E.; Honma, I. Enhanced cyclic performance and lithium storage capacity of $\mathrm{SnO}_{2} /$ graphene nanoporous electrodes with three-dimensionally delaminated flexible structure. Nano Lett. 2008, 9, 72-75. [CrossRef] [PubMed]

59. Wang, S.; Jiang, S.P.; Wang, X. Microwave-assisted one-pot synthesis of metal/metal oxide nanoparticles on graphene and their electrochemical applications. Electrochim. Acta 2011, 56, 3338-3344. [CrossRef]

60. Park, S.-H.; Kim, H.-K.; Ahn, D.-J.; Lee, S.-I.; Roh, K.C.; Kim, K.-B. Self-assembly of Si entrapped graphene architecture for high-performance Li-ion batteries. Electrochem. Commun. 2013, 34, 117-120. [CrossRef]

61. Wang, J.-Z.; Zhong, C.; Chou, S.-L.; Liu, H.-K. Flexible free-standing graphene-silicon composite film for lithium-ion batteries. Electrochem. Commun. 2010, 12, 1467-1470. [CrossRef]

62. Tang, H.; Zhang, Y.; Xiong, Q.; Cheng, J.; Zhang, Q.; Wang, X.; Gu, C.; Tu, J. Self-assembly silicon/porous reduced graphene oxide composite film as a binder-free and flexible anode for lithium-ion batteries. Electrochim. Acta 2015, 156, 86-93. [CrossRef]

63. Tao, H.-C.; Fan, L.-Z.; Mei, Y.; Qu, X. Self-supporting Si/Reduced Graphene Oxide nanocomposite films as anode for lithium ion batteries. Electrochem. Commun. 2011, 13, 1332-1335. [CrossRef]

64. Zhou, M.; Cai, T.; Pu, F.; Chen, H.; Wang, Z.; Zhang, H.; Guan, S. Graphene/carbon-coated Si nanoparticle hybrids as high-performance anode materials for Li-ion batteries. ACS Appl. Mater. Interfaces 2013, 5, 3449-3455. [CrossRef] [PubMed] 
65. Chabot, V.; Feng, K.; Park, H.W.; Hassan, F.M.; Elsayed, A.R.; Yu, A.; Xiao, X.; Chen, Z. Graphene wrapped silicon nanocomposites for enhanced electrochemical performance in lithium ion batteries. Electrochim. Acta 2014, 130, 127-134. [CrossRef]

66. Chen, D.; Yi, R.; Chen, S.; Xu, T.; Gordin, M.L.; Wang, D. Facile synthesis of graphene-silicon nanocomposites with an advanced binder for high-performance lithium-ion battery anodes. Solid State Ion. 2014, 254, 65-71. [CrossRef]

67. Su, M.; Wang, Z.; Guo, H.; Li, X.; Huang, S.; Xiao, W.; Gan, L. Enhancement of the Cyclability of a Si/Graphite@Graphene composite as anode for Lithium-ion batteries. Electrochim. Acta 2014, 116, 230-236. [CrossRef]

68. Xiang, H.; Zhang, K.; Ji, G.; Lee, J.Y.; Zou, C.; Chen, X.; Wu, J. Graphene/nanosized silicon composites for lithium battery anodes with improved cycling stability. Carbon 2011, 49, 1787-1796. [CrossRef]

69. Eoma, K.; Joshi, T.; Bordes, A.; Do, I.; Fuller, T. The design of a Li-ion full cell battery using a nano silicon and nano multi-layer graphene composite anode. J. Power Sources 2014, 249, 118-124. [CrossRef]

70. Luo, J.; Zhao, X.; Wu, J.; Jang, H.D.; Kung, H.H.; Huang, J. Crumpled Graphene-Encapsulated Si Nanoparticles for Lithium Ion Battery Anodes. J. Phys. Chem. Lett. 2012, 3, 1824-1829. [CrossRef] [PubMed]

71. Yi, R.; Zai, J.; Dai, F.; Gordin, M.L.; Wang, D. Dual Conductive Network-Enabled Graphene/Si-C Composite Anode with High Areal Capacity for Lithium-ion Batteries. Nano Energy 2014. [CrossRef]

72. Xin, X.; Zhou, X.; Wang, F.; Yao, X.; Xu, X.; Zhu, Y.; Liu, Z. A 3D porous architecture of Si/graphene nanocomposite as high-performance anode materials for Li-ion batteries. J. Mater. Chem. 2012, 22, 7724-7730. [CrossRef]

73. De Guzman, R.C.; Yang, J.; Cheng, M.M.-C.; Salley, S.O.; Simon Ng, K.Y. Effects of graphene and carbon coating modifications on electrochemical performance of silicon nanoparticle/graphene composite anode. J. Power Sources 2014, 246, 335-345. [CrossRef]

74. Li, H.; Lu, C.; Zhang, B. A straightforward approach towards Si@C/graphene nanocomposite and its superior lithium storage performance. Electrochim. Acta 2014, 120, 96-101. [CrossRef]

75. Ye, Y.-S.; Xie, X.-L.; Rick, J.; Chang, F.-C.; Hwang, B.-J. Improved anode materials for lithium-ion batteries comprise non-covalently bonded graphene and silicon nanoparticles. J. Power Sources 2014, 247, 991-998. [CrossRef]

76. Kannan, A.G.; Kim, S.H.; Yang, H.S.; Kim, D.-W. Silicon nanoparticles grown on a reduced graphene oxide surface as high-performance anode materials for lithium-ion batteries. RSC Adv. 2016, 6, 25159-25166. [CrossRef]

77. Ji, J.; Ji, H.; Zhang, L.L.; Zhao, X.; Bai, X.; Fan, X.; Zhang, F.; Ruoff, R.S. Graphene-Encapsulated Si on Ultrathin-Graphite Foam as Anode for High Capacity Lithium-Ion Batteries. Adv. Mater. 2013, 25, 4673-4677. [CrossRef] [PubMed]

78. Li, N.; Jin, S.; Liao, Q.; Cui, H.; Wang, C.X. Encapsulated within graphene shell silicon nanoparticles anchored on vertically aligned graphene trees as lithium ion battery anodes. Nano Energy 2014, 5, 105-115. [CrossRef]

79. Li, Z.F.; Zhang, H.; Liu, Q.; Liu, Y.; Stanciu, L.; Xie, J. Novel pyrolyzed polyaniline-grafted silicon nanoparticles encapsulated in graphene sheets as li-ion battery anodes. ACS Appl. Mater. Interfaces 2014, 6, 5996-6002. [CrossRef] [PubMed]

80. Hwang, T.H.; Lee, Y.M.; Kong, B.-S.; Seo, J.-S.; Choi, J.W. Electrospun core-shell fibers for robust silicon nanoparticle-based lithium ion battery anodes. Nano Lett. 2012, 12, 802-807. [CrossRef] [PubMed]

81. Bai, X.; Yu, Y.; Kung, H.H.; Wang, B.; Jiang, J. Si@SiOx/graphene hydrogel composite anode for lithium-ion battery. J. Power Sources 2016, 306, 42-48. [CrossRef]

82. Günes, F. A direct synthesis of Si-nanowires on 3D porous graphene as a high performance anode material for Li-ion batteries. RSC Adv. 2016, 6, 1678-1685. [CrossRef]

83. Lu, Z.; Zhu, J.; Sim, D.; Shi, W.; Tay, Y.Y.; Ma, J.; Hng, H.H.; Yan, Q. In situ growth of Si nanowires on graphene sheets for Li-ion storage. Electrochim. Acta 2012, 74, 176-181. [CrossRef]

84. Wang, B.; Li, X.; Zhang, X.; Luo, B.; Jin, M.; Liang, M.; Dayeh, S.; Picraux, S.T.; Zhi, L. Adaptable Silicon-Carbon Nanocables Sandwiched between Reduced Graphene Oxide Sheets as Lithium Ion Battery Anodes. ACS Nano 2013, 7, 1437-1445. [CrossRef] [PubMed]

85. Shim, J.; Striebel, K.A. Effect of electrode density on cycle performance and irreversible capacity loss for natural graphite anode in lithium-ion batteries. J. Power Sources 2003, 119, 934-937. [CrossRef] 
86. Smekens, J.; Gopalakrishnan, R.; Van den Steen, N.; Omar, N.; Hegazy, O.; Hubin, A.; Van Mierlo, J. Influence of electrode density on the performance of Li-ion batteries: Experimental and simulation results. Energies 2016, 9, 104. [CrossRef]

87. Pribat, D. Rechargeable Batteries-Materials, Technologies and New Trends; Zhang, Z., Zhang, S.S., Eds.; Springer: Berlin/Heidelberg, Germany, 2015. [CrossRef]

88. Nitta, N.; Yushin, G. High-capacity anode materials for lithium-ion batteries: Choice of elements and structures for active particles. Part. Part. Syst. Charact. 2014, 31, 317-336. [CrossRef]

89. Chae, S.; Ko, M.; Kim, K.; Ahn, K.; Cho, J. Confronting Issues of the Practical Implementation of Si Anode in High-Energy Lithium-Ion Batteries. Joule 2017, 1, 47-60. [CrossRef]

90. Gao, X.; Jang, J.; Nagase, S. Hydrazine and thermal reduction of graphene oxide: Reaction mechanisms, product structures, and reaction design. J. Phys. Chem. C 2009, 114, 832-842. [CrossRef]

91. Chen, W.; Yan, L.; Bangal, P.R. Preparation of graphene by the rapid and mild thermal reduction of graphene oxide induced by microwaves. Carbon 2010, 48, 1146-1152. [CrossRef]

92. Some, S.; Kim, Y.; Yoon, Y.; Yoo, H.; Lee, S.; Park, Y.; Lee, H. High-quality reduced graphene oxide by a dual-function chemical reduction and healing process. Sci. Rep. 2013, 3, 1929. [CrossRef] [PubMed]

93. Yao, Y.Q.; Cen, Y.J.; Sisson, R.D.; Liang, J.Y. A Synthesize Protocol for Graphene Nanosheets. In Proceedings of the 4th Asia Conference on Mechanical and Materials Engineering, Kuala Lumpur, Malaysia, 14-18 July 2016; pp. 3-6.

94. Chen, J.; Bie, L.; Sun, J.; Xu, F. Enhanced electrochemical performances of silicon nanotube bundles anode coated with graphene layers. Mater. Res. Bull. 2016, 73, 394-400. [CrossRef]

95. Ni, Z.H.; Yu, T.; Lu, Y.H.; Wang, Y.Y.; Feng, Y.P.; Shen, Z.X. Uniaxial strain on graphene: Raman spectroscopy study and band-gap opening. ACS Nano 2008, 2, 2301-2305. [CrossRef] [PubMed]

96. Ferrari, A.; Meyer, J.; Scardaci, V.; Casiraghi, C.; Lazzeri, M.; Mauri, F.; Piscanec, S.; Jiang, D.; Novoselov, K.; Roth, S. Raman spectrum of graphene and graphene layers. Phys. Rev. Lett. 2006, 97, 187401. [CrossRef] [PubMed]

97. Wang, Y.Y.; Ni, Z.H.; Yu, T.; Shen, Z.X.; Wang, H.M.; Wu, Y.H.; Chen, W.; Shen Wee, A.T. Raman studies of monolayer graphene: The substrate effect. J. Phys. Chem. C 2008, 112, 10637-10640. [CrossRef]

98. Ferrari, A.C. Raman spectroscopy of graphene and graphite: Disorder, electron-phonon coupling, doping and nonadiabatic effects. Solid State Commun. 2007, 143, 47-57. [CrossRef]

99. Cançado, L.; Jorio, A.; Pimenta, M. Measuring the absolute Raman cross section of nanographites as a function of laser energy and crystallite size. Phys. Rev. B 2007, 76, 064304. [CrossRef]

100. Ferreira, E.M.; Moutinho, M.V.; Stavale, F.; Lucchese, M.; Capaz, R.B.; Achete, C.; Jorio, A. Evolution of the Raman spectra from single-, few-, and many-layer graphene with increasing disorder. Phys. Rev. B 2010, 82, 125429. [CrossRef]

101. Feng, L.; Liu, Z. Graphene in biomedicine: Opportunities and challenges. Nanomedicine 2011, 6, 317-324. [CrossRef] [PubMed]

102. Chen, J.; Badioli, M.; Alonso-González, P.; Thongrattanasiri, S.; Huth, F.; Osmond, J.; Spasenović, M.; Centeno, A.; Pesquera, A.; Godignon, P. Optical nano-imaging of gate-tunable graphene plasmons. Nature 2012, 487, 77-81. [CrossRef] [PubMed]

103. Cen, Y. Si/C Nanocomposites for Li-Ion Battery Anode. Ph.D. Thesis, Worcester Polytechnic Institute, Worcester, MA, USA, 2017.

(C) 2018 by the authors. Licensee MDPI, Basel, Switzerland. This article is an open access article distributed under the terms and conditions of the Creative Commons Attribution (CC BY) license (http:/ / creativecommons.org/licenses/by/4.0/). 